\title{
Morphological and Rheological Identification of Cocci Lactic Acid Bacteria
}

\author{
Elzeini HM$^{1}$, Ali AA ${ }^{1}$, Nasr $\mathbf{N F}^{2}$, Awad AA ${ }^{1}$ and Hassan AA
}

${ }^{1}$ Department of Dairy Science, Cairo University, Giza, Egypt

${ }^{2}$ Department of Agricultural Microbiology, Faculty of Agriculture, Cairo University, Giza, Egypt

\begin{abstract}
Lactic Acid Bacteria (LAB) widely distributed in nature and play an important role in many food fermentations Bacterial cell morphology is useful and valuable parameters used in characterization of any organisms. Therefore, cell morphological shape and size of six strains of cocci LAB grown in two different media (M17 and RSM) were studied using scanning electron microscope (SEM) and image analysis technique. Topographical images reveal spherical or pseudo-spherical structures with height profiles and variation in size which occurred singly or in pairs, chains and tetrads. Cocci cells had a wide range of diameters $(0.79-1.52 \mu \mathrm{m})$ with wide cells perimeters of 2.69 up to $5.54 \mu \mathrm{m}$. Cells growing in broth medium (M17) had higher surface areas and volumes being from $0.26 \mu \mathrm{m}^{3}$ to 1.82 $\mu \mathrm{m}^{3}$. Some cocci cells were far away from being a perfect circle (0.639) while others had close to circle shapes. Cocci cells had a different orientation angles and surfaces seemed to have heights or extrudes with external boundary which were either a sharp outline or a rough surface. Cells hardness and wall thickness had an effect negatively or positively depending on the strain and growing medium.
\end{abstract}

Rheological properties (viscosity, shear stress and torque) recorded different values. Shear stress followed the same trend as viscosity with maximum reached at different times (12 up to17 h). Clotting time was 11 up to17.7 h depending on the strain. According to acid production development, the fastest strain reached the iso-electric point $(\mathrm{pH}$ 4.6) was Str. thermophilus (12 h).

Keywords: Lactic acid bacteria; Bacterial cell morphology; Cocci LAB; M17 and RSM; Topographical images; Rheological properties; Shear stress; Clotting time; S. thermophiles

\section{Introduction}

Lactic acid bacteria (LAB) widely distributed in nature and play an important role in many foods and feed fermentations [1]. Bacterial cell size and shape are still useful and valuable morphological characteristic which may be used in the identification of bacteria because morphological structural features are usually genetically stable and easy to study and analyze $[2,3]$.

Advanced microscopes can now, in a single day, easily collect thousands of high resolution images of cells from time lapse experiments [4]. However, a bottleneck exists at the image analysis stage. Still, for most applications, image cytometry (automated cell image analysis) is strongly preferable to analysis by eye. In fact, in some cases image cytometry is absolutely required to extract the full spectrum of information present in biological images. First, while human observers typically score one or at most a few cellular features, image cytometry simultaneously yields many informative measures of cells, including the intensity and localization of each cellular component (DNA or protein), as well as the number, size and shape of subcellular compartments. Image-based analysis is thus versatile, inherently multiplexed, and high in information content.

Second, human-scored image analysis is qualitative; by contrast, automated analysis rapidly produces consistent, quantitative measures for every image. Measuring a large number of features, even features undetectable by eye, has proven useful for screening as well as cytological/cytometric profiling, which can group similar cells [5-8].

Third, image cytometry individually measures each cell rather than producing a score for the entire image. Because individual cells' responses are inhomogeneous, which have proven much more powerful than whole-population data for clustering genes, deriving causal networks and classifying protein localization [9-11].
Fourth, quantitative image analysis is able to detect some features that are not readily detectable by a human observer. The purposes of this study were developing a set of data for LAB using a computationally quick procedure for extracting textural features of images and discussing the usefulness of these features as a tool for their characterization, in addition to determining the differences in rheological properties of lactic acid bacteria under the study.

\section{Materials and Methods}

\section{Bacterial strains}

Six strains of LAB (pure frozen cultures of Enterococcus faecalis $780 \mathrm{~N}$, Enterococcus faecium $744 \mathrm{~N}$, Lactococcus lactis subsp. lactis $774 \mathrm{~N}$, Lactococcus lactis subsp. cremoris 0-114, and Streptococcus thermophilus $779 \mathrm{~N}$ ) were obtained from the laboratory of Dairy Biotechnology of Faculty of Agriculture, Alexandria University while, Pediococcus acidilactici EMCC1690 was obtained from Cairo Mircen Microbiological Resources Center of Ain-Shams University.

\section{Growth media}

M17 broth: It contains (g/l): Tryptone (5.0), Soya peptone (5.0), meat digest (5.0), yeast extract (2.5), ascorbic acid (0.5), magnesium sulphate (0.25), di-sodium-glycerophosphat (19.0), pH $6.9 \pm 2$ [12].

Reconstituted skim milk (RSM): Reconstituted low heat skim milk

${ }^{*}$ Corresponding author: Elzeini H. M., Department of Dairy Science, Cairo University, Giza, Egypt, Tel: +201000752906; E-mail: dr_hodazeini@yahoo.com

Received December 17, 2015; Accepted January 10, 2017; Published January 17,2017

Citation: Elzeini HM, Ali AA, Nasr NF, Awad AA, Hassan AA (2017) Morphological and Rheological Identification of Cocci Lactic Acid Bacteria. J Microb Biochem Technol 9: 519-526. doi: 10.4172/1948-5948.1000337

Copyright: (c) 2017 Elzeini HM, et al. This is an open-access article distributed under the terms of the Creative Commons Attribution License, which permits unrestricted use, distribution, and reproduction in any medium, provided the original author and source are credited. 
powder (Mefad, Egypt), with $11 \%$ T.S (w/v), was sterilized at $115^{\circ} \mathrm{C} / 7$ min, then cooled overnight ( $\mathrm{pH}$ 6.7) [13].

\section{Preparation of bacterial cells suspensions}

M17 broth cells suspensions: Cultures of Lactic acid bacteria strains (frozen stocks) were separately sub-cultured in $\mathrm{M} 17$ broth at $32^{\circ} \mathrm{C}$ for $L$. lactis subsp. lactis $774 \mathrm{~N}$, L. lactis subsp. cremoris $0-114$ and $P$. acidilactici EMCC 1690 and at $40^{\circ} \mathrm{C}$ for $S$. thermophilus $779 \mathrm{~N}$, E. faecium $744 \mathrm{~N}$ and E. faecalis $780 \mathrm{~N}$ to the third subculture of the strains.

RSM cells suspensions: The activated cultures (in M17 broth), were grown in reconstituted skim milk (RSM) under the same conditions of M17 broth until a $\mathrm{pH}$ of 4.7 . Casein was precipitated by $0.2 \%(\mathrm{w} / \mathrm{v})$ EDTA $(1: 10 \mathrm{v} / \mathrm{v})$. Cells suspension was obtained from the collected supernatant.

Sample preparation for scanning electron microscope: Bacterial cells suspensions of M17 broth and RSM were centrifuged at 3000 rpm for $1 \mathrm{~min}$. To fix the protein, pellets (bacterial cells) were fixed in $3 \%$ glutaraldehyde in $0.1 \mathrm{M}$ phosphate buffer at $\mathrm{pH} 7.2$ for $2 \mathrm{~h}$, followed by washing several times in $0.1 \mathrm{M}$ phosphate buffer for 15 min intervals. Samples were dehydrated in series of aqueous ethanol solutions $(25 \%, 50 \%, 75 \%, 95 \%$ and $100 \%)$ for $5 \mathrm{~min}$ each, dried to critical point using $\mathrm{CO}_{2}$ in a Critical Point Dryer (Polaron, Waterford, England) and mounted on aluminum SEM stubs, sputter-coated with gold (Spi module sputter coater, spi supplies division of structure probe. Samples were examined at 10-25 KV with SEM. Because the method relies on the accuracy of measurements, care was taken to always use the microscope at the same viewing angle.

\section{Image analysis}

For image analysis, Scanning Prop Image Processor (SPIP) program 6.0.6 (BETA, Denmark) was used which enables the user to manipulate lateral calibration and unit cell detection to account for magnification differences in each image. After calibration of the program according to the scale bar on the micrographs, cells were magnified for better definition of the cell edges; the cells were then measured by moving the pointer from one cell edge to the other side edge. Detection and quantification of bacterial cell were done using the polygon measure shape (Figure 1). The program was keeping the measurements in memory and calculating some statistical values). Several morphological and geometrical parameters such as (diameter, area, length, breadth, perimeter, roundness, compactness, solidity, hardness, roughness and wall thickness) were calculated by the system as follows:

Area: The Area is calculated from the shapes periphery, i.e., the closed polygon that surrounds the feature.

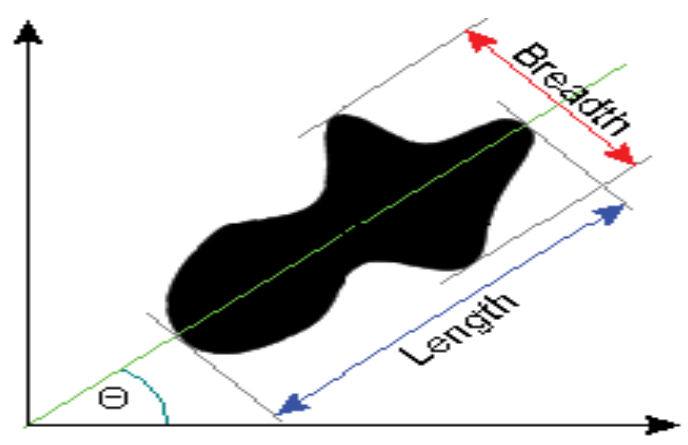

Figure 1: Polygon shape used for measuring the morphological parameters.
$\operatorname{Area}($ polygon $)=\frac{\sum_{i \in}\left(\chi_{i}+\chi_{i-1}\right) \cdot\left(y_{i}-y_{i-1}\right)}{2}$

Diameter: The diameter (or Heywood diameter) is expressed as the diameter of a circle having an area equivalent to the shape's area.

Diameter $=\sqrt{\frac{4}{\pi} \cdot \text { Area }}$

Length: Length is defined as the longest cord along the angle $\theta$ given by the moment's axis to the $\mathrm{x}$-axis.

Breadth: Breadth (or width) is defined as the longest cord perpendicular to the angle $\theta$ given by the moment's axis to the $\mathrm{x}$-axis (Figure 1). Breadth is the extension of the bounding rectangle in the vertical direction.

Perimeter: For Polygon shapes the perimeter is calculated from the shape's contour as:

$$
p=\sum \sqrt{\left(\chi_{i}-\chi_{i-1}\right)^{2}+\left(y_{i}-y_{i-1}\right)^{2}}
$$

Volume: Volume is the maximum of the found material volume and void volumes:

Volume $=$ Max $\{$ material volume + void volume $\}$

Where the material volume equals the volume of all points having a $\mathrm{Z}$ value higher than the mean contour height

Material volume $=\sum\left(\mathrm{Z}(\mathrm{x}, \mathrm{y})-\mathrm{Z}_{\mathrm{MSH}}\right) \cdot \mathrm{dxdy}$

Void Volume equals the volume of all points having a $Z$ value lower than the mean contour height. This value will always be positive

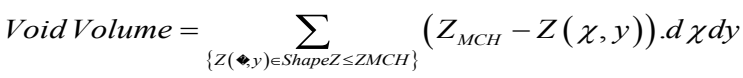

Where $\mathrm{dx}$ and dy are the point spacing in the $\mathrm{x}$ and $\mathrm{y}$ directions of the image, respectively.

Roundness: Roundness describes the shape's resemblance to a circle. The roundness factor of a shape will approach 1.0 the closer the shape resembles a circle.

$$
\text { Roundness }=\frac{4 \cdot \text { Area }}{\pi \cdot \text { Length }^{2}}
$$

Compactness: Compactness is a measure expressing how compact a feature is:

Compactness $=\frac{\text { Diameter }}{\text { Length }}=\frac{\sqrt{\frac{4-\text { Area }}{\pi}}}{\text { Length }}$

Solidity: Solidity is a measure describing the resemblance of the shape's area with its convex area.

$$
\text { Solidity }=\frac{\text { Area }}{\text { Convex Area }}
$$

Rheological parameters measurements: Rheological measurements of milk inoculated with bacteria (viscosity, shear stress and torque) were carried out in triplicates over temperature of $25^{\circ} \mathrm{C}$ using a concentric cylinder Brookfield Programmable viscometer (Model DV-II; Brookfield Engineering Laboratories, USA) with UL adaptor and ULA spindle over a shear rate of $12.2 \mathrm{~s}^{-1}$. WinGather version 1.1, (Brookfield Engineering Laboratories, Inc., Copyright ${ }^{\circ}$ 1995) software was used to collect, store and plot the data on a personal computer connected to the viscometer.

Acidifying activity of LAB strains: $3 \%$ of the activated strains were inoculated into sterile reconstituted skim milk (RSM) and used for 
periodically monitoring $\mathrm{pH}$ each $2 \mathrm{~h}$, acidity was determined according to $[14,15]$. All treatments were done in triplicates.

\section{Statistical analysis}

The two-way statistical analysis of variance (ANOVA), mean separation and correlation required subprogram of MSTAT microcomputer statistical program was applied to evaluate morphological and rheological parameters of various cocci strains of lactic acid bacteria. Simple and multiple linear regression analysis were applied and the student " $t$ " test was used to test mean at $\mathrm{p}<0.05[16,17]$.

\section{Results and Discussion}

Six cocci strains of LAB were morphologically investigated using SEM (Figure 2). The cells were photographed and representative images were shown in Figure 2. Topographical images revealed spherical or pseudo-spherical structures with height profiles and variation in size which occurred singly, pairs and chains. Images produced from scans were analyzed using SPIP software. However, most of the functions in different software were similar and thus the results were comparable. Bright and dark areas in the images corresponded to peaks and troughs in the objects. Commonly, different scales are used in the vertical and horizontal axes. There were many offline operations for getting object properties. For example, sectional profile analysis was used to measure depth, height, and width of specimens. Roughness analysis was performed over an entire image or a selected part of the image to describe the surface status of the bacteria. When viewing an entire cell, the large number of individual components being visualized depending on the cell size [18].

\section{Morphological characteristics of LAB strains}

Bacterial cell diameter: Bacterial cells had almost spherical structure with a wide range of diameters $(0.79$ to $1.51 \mu \mathrm{m})(0.79$ to $1.51 \mu \mathrm{m}$ ). (Table 1) shows the average diameters for different cocci strains of LAB with standard deviations deviations. [19] stated that cells of coccus bacteria have spherical cells range of $0.5-2 \mu \mathrm{m}$ in diameter which is wider than what was obtained in this work. This difference may be due to the bacterial strains, technique and the condition of both works.

The highest cells diameter was obtained as $1.51 \mu \mathrm{m}$ for Lactococcus lactis subsp. cremoris, while the smallest one was $0.79 \mu \mathrm{m}$ for Pediococcus acidilactici. The bacterial cell diameters' averages were 1.348, 1.374, $1.17,1.37,1.40$ and $0.88 \mu \mathrm{m}$ for E. faecalis, E. faecium, $S$. thermophilus, L. lactis subsp. lactis, L. lactis subsp. cremoris and P. acidilactici grown in M17 broth, respectively. When they grew in milk, the cells' diameters

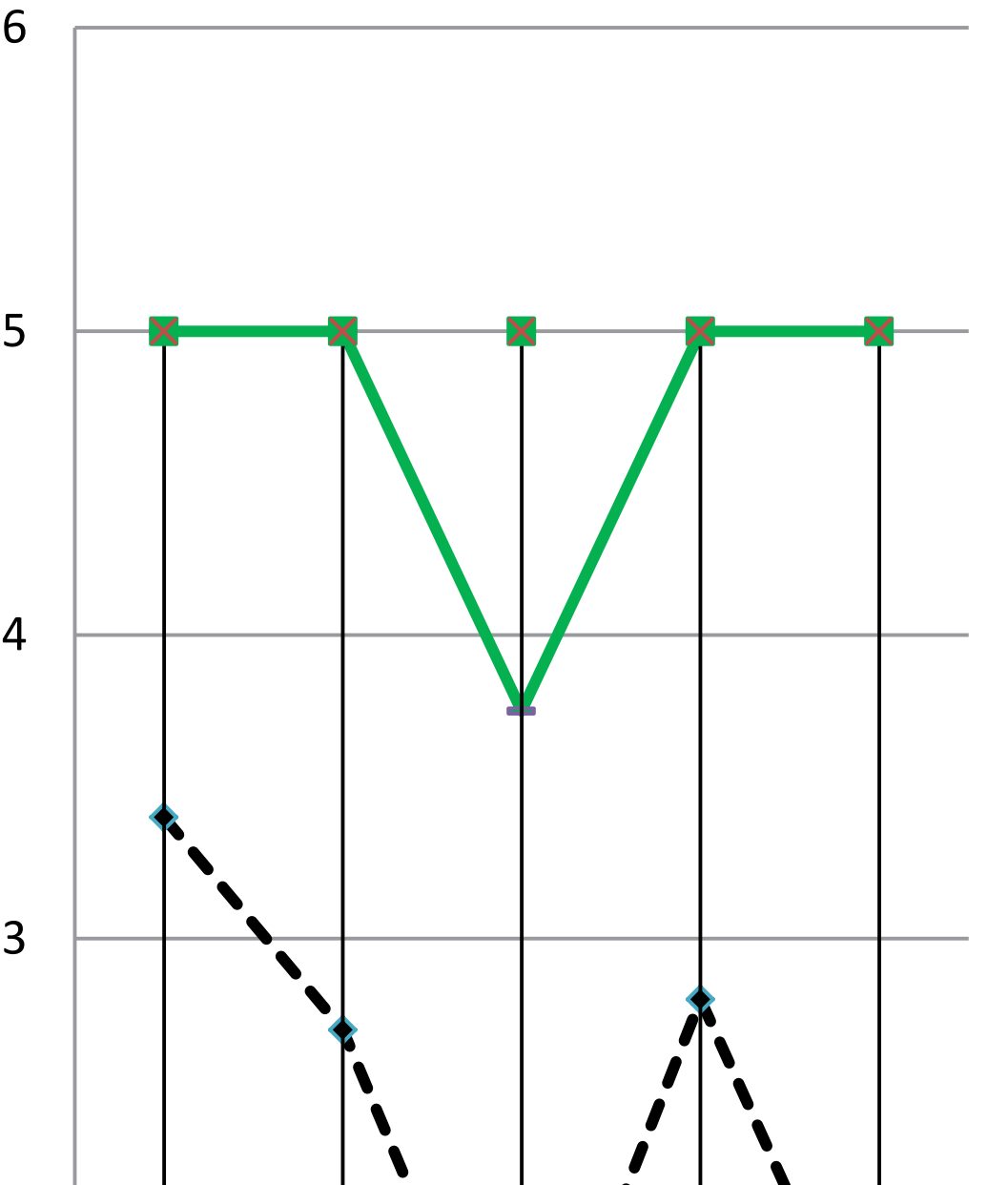

Figure 2: Micrograph of Enterococcus faecium, Enterococcus faecalius and Lactococcus cremoris (A, C, E) in broth media and (B, D, F) in milk, and Micrograph of Streptococcus thermophilus, Lactococcus lactis and Pediococcus acidilactica $(\mathrm{G}, \mathrm{I}, \mathrm{K})$ in broth media and $(\mathrm{H}, \mathrm{J}, \mathrm{L})$ in milk. 
averages were reduced significantly $(\mathrm{P}<0.001)$ to $1.26,1.25,1.29,1.17$, 0.971 and $0.99 \mu \mathrm{m}$, respectively. Bacterial strain and type of growing medium significantly affected $(L S D=0.0799)(\alpha=0.05)$ cells diameters.

Similarly, [20] reported that the mean ranges of diameters of different strains growing in milk are (0.84-1.14), (0.84-0.98), (1.02$1.32)$ and (0.77-1.17) $\mu \mathrm{m}$ for E. faecalis, E. faecium, S. thermophilus and L. lactis subsp. lactis, respectively, with acceptable standard deviation low or around $10 \%$ of the mean value. [21] found similar diameters (0.5-1.5 um) also for Lactococcus lactis cells.

Bacterial cells breadth: Imperfect spherical shapes show length and width Bacterial cells breadth: Imperfect spherical shapes show length and width. The averages of bacterial cells width along with standard deviation for different strains were shown in Tables 1 and 2 . The highest width was found with $L$. lactis subsp. cremoris $(1.47 \mu \mathrm{m})$ grown in M17 broth and L. lactis subsp. lactis $(1.44 \mu \mathrm{m})$ grown in milk, while, the least breadths were found with $P$. acidilactici $(0.62 \mu \mathrm{m})$ grown in M17 broth and L. lactis subsp. cremoris $(0.74 \mu \mathrm{m})$ grown in milk.

However, an increase in the degree of bacterial cells elongation is believed to be an indicator of bacterial cells distortion. While, no significant differences at $\alpha=0.05$ (LSD $=0.075$ ) in breadth were found among E. faecalis, E. faecium and L. lactis subsp. lactis grown in M17 broth, with strains variation, significant influences $(\mathrm{P}<0.001)$ were recognized in width.

Bacterial cells length: The averages of bacterial cells lengths were presented in Tables 1 and 2. The highest lengths were found with $L$. lactis subsp. cremoris $(1.85 \mu \mathrm{m})$ grown in M17 broth and E. faecium $(1.87 \mu \mathrm{m})$ grown in milk, while the least lengths were found with $P$. acidilactici $(0.95 \mu \mathrm{m})$ grown in M17 broth and L. lactis subsp. cremoris $(0.91 \mu \mathrm{m})$ grown in milk. As so far, the same bacteria showed the same minimum values for breadths. Within treatments, the growing medium caused insignificant differences for $E$. faecalis and $P$. acidilacici lengths ( $\mathrm{LSD}=0.119$ at 0.05 a level). Bacterial species $(\mathrm{P}<0.001)$, type of growing medium $(\mathrm{P}<0.01)$ and the interaction between the two factors $(\mathrm{P}<0.05)$ influenced the bacterial lengths.

Bacterial cells perimeter: Wide perimeter ranges from 5.54 for $L$. lactis subsp. lactis to $2.69 \mu \mathrm{m}$ for $P$. acidilactici with an average from $4.70 \mu \mathrm{m}$ for L. lactis subsp. cremoris grown in M17 broth to $2.98 \mu \mathrm{m}$ grown in milk. Tables 1 and 2 showed the perimeters of lactic acid bacterial strains as a function of strain and type of medium used for growing. Perimeter of E. faecium did not differ from L. lactis subsp. lactis grown in milk (LSD=0.381). The same results were found with $L$. lactis subsp. cremoris grown in milk and $P$. acidilactici grown in M17 broth and milk at $\alpha=0.05$.

Bacterial cells surface area: The maximum surface area was obtained for L. lactis subsp. cremoris $\left(1.80 \mu \mathrm{m}^{2}\right)$ grown in M17 broth, while $P$. acidilactici had the minimum $\left(0.49 \mu \mathrm{m}^{2}\right)$ surface area. The bacterial cell surface areas' averages were 1.50, 1.44, 1.08, 1.40, 1.43 and $0.65 \mu \mathrm{m}^{2}$ for E. faecalis, E. faecium, S. thermophilus, L. lactis subsp. lactis, L. lactis subsp. cremoris and P. acidilactici grown in M17 broth, respectively. However when grown in milk, the average surface areas were reduced to $1.17,1.28,0.99,1.34$ and $0.69 \mu \mathrm{m}^{2}$, respectively with exception of $P$. acidilactici which increased to $0.73 \mu \mathrm{m}^{2}$. The same trend was observed with diameter data.

Bacterial cells surface volume: The smallest bacterial cells volume was recognized with $P$. acidilactici $\left(0.26 \mu \mathrm{m}^{3}\right)$, while Lc. lactis subsp. cremoris scored the highest volume value $\left(1.82 \mu \mathrm{m}^{3}\right)$ when both grown in M17 broth. The highest mean was found for L. lactis subsp. cremoris $(1.70 \pm 0.40)$. All strains differed significantly within treatments ( $\mathrm{LSD}=0.178$ at 0.05 a level) except for L. lactis subsp. cremoris grown in milk and $P$. acidilactici grown in both growing media.

Volume of the bacteria was affected significantly $(\mathrm{P}<0.01)$ by strain variation. On the other hand, type of growing medium did not affect the cells volume $(P>0.05)$, while, the interaction between the two factors significantly $(\mathrm{P}<0.05)$ altered the volume.

Table 1: Mean, standard deviation (SD), coefficient of variation (Co. Var.) of morphological and geometrical parameters of LAB grown in M17 (Selective broth medium).

\begin{tabular}{|c|c|c|c|c|c|c|c|c|c|c|}
\hline \multicolumn{11}{|c|}{ Mean \pm SD } \\
\hline & $\begin{array}{l}\text { Diameter } \\
(\mu \mathrm{m})\end{array}$ & $\begin{array}{c}\text { Breadth } \\
(\mu \mathrm{m})\end{array}$ & Length $(\mu \mathrm{m})$ & $\begin{array}{l}\text { Perimeter } \\
(\mu \mathrm{m})\end{array}$ & Area $\left(\mu \mathrm{m}^{2}\right)$ & Volume $\left(\mu \mathrm{m}^{3}\right)$ & $\begin{array}{l}\text { Roundness } \\
(0-1)\end{array}$ & $\begin{array}{l}\text { Solidity } \\
(0-1)\end{array}$ & $\begin{array}{c}\text { Compactness } \\
(0-1)\end{array}$ & $\begin{array}{l}\text { Wall thickness } \\
\qquad(\mu \mathrm{m})\end{array}$ \\
\hline E. faecalis & $1.34 \pm 0.08$ & $1.20 \pm 0.12$ & $1.62 \pm 0.10$ & $4.93 \pm 0.38$ & $1.50 \pm 0.19$ & $1.28 \pm 0.14$ & $0.69 \pm 0.09$ & $0.940 \pm 0.032$ & $0.834 \pm 0.055$ & $0.270 \pm 0.072$ \\
\hline E. faecium & $1.37 \pm 0.06$ & $1.11 \pm 0.08$ & $1.74 \pm 0.13$ & $4.68 \pm 0.46$ & $1.44 \pm 0.13$ & $1.36 \pm 0.17$ & $0.62 \pm 0.06$ & $0.981 \pm 0.018$ & $0.783 \pm 0.038$ & $0.292 \pm 0.041$ \\
\hline S. thermophilus & $1.16 \pm 0.08$ & $0.98 \pm 0.06$ & $1.54 \pm 0.13$ & $4.34 \pm 0.39$ & $1.08 \pm 0.15$ & $0.82 \pm 0.06$ & $0.56 \pm 0.05$ & $0.957 \pm 0.023$ & $0.758 \pm 0.036$ & $0.240 \pm 0.114$ \\
\hline L. lactis & $1.37 \pm 0.07$ & $1.20 \pm 0.08$ & $1.62 \pm 0.12$ & $5.08 \pm 0.60$ & $1.40 \pm 0.16$ & $1.37 \pm 0.17$ & $0.71 \pm 0.09$ & $0.951 \pm 0.026$ & $0.851 \pm 0.053$ & $0.203 \pm 0.065$ \\
\hline L. cremoris & $1.40 \pm 0.10$ & $1.16 \pm 0.13$ & $1.65 \pm 0.12$ & $4.79 \pm 0.38$ & $1.43 \pm 0.22$ & $1.70 \pm 0.40$ & $0.73 \pm 0.10$ & $0.975 \pm 0.021$ & $0.858 \pm 0.061$ & $0.271 \pm 0.037$ \\
\hline P. acidilactici & $0.88 \pm 0.07$ & $0.73 \pm 0.10$ & $1.09 \pm 0.10$ & $3.19 \pm 0.19$ & $0.65 \pm 0.11$ & $0.37 \pm 0.12$ & $0.66 \pm 0.10$ & $0.951 \pm 0.034$ & $0.824 \pm 0.061$ & $0.283 \pm 0.065$ \\
\hline Co. Var.\% & 7.63 & 10.63 & 9.74 & 10.59 & 3.63 & 21.73 & 13.2 & 4.58 & 6.52 & 29.84 \\
\hline
\end{tabular}

Table 2: Mean, standard deviation (SD), coefficient of variation (Co. Var.) of morphological and geometrical parameters of LAB grown in RSM (Reconstituted skim milk medium).

\begin{tabular}{|c|c|c|c|c|c|c|c|c|c|c|}
\hline \multicolumn{11}{|c|}{ Mean \pm SD } \\
\hline & $\begin{array}{l}\text { Diameter } \\
(\mu \mathrm{m})\end{array}$ & $\begin{array}{c}\text { Breadth } \\
(\mu \mathrm{m})\end{array}$ & $\begin{array}{l}\text { Length } \\
(\mu \mathrm{m})\end{array}$ & $\begin{array}{l}\text { Perimeter } \\
\quad(\mu \mathrm{m})\end{array}$ & $\begin{array}{l}\text { Area } \\
\left(\mu \mathrm{m}^{2}\right)\end{array}$ & $\begin{array}{c}\text { Volume } \\
\left(\mu \mathrm{m}^{3}\right)\end{array}$ & $\begin{array}{c}\text { Roundness } \\
(0-1)\end{array}$ & $\begin{array}{c}\text { Solidity } \\
(0-1)\end{array}$ & $\begin{array}{c}\text { Compactness } \\
(0-1)\end{array}$ & $\begin{array}{l}\text { Wall thickness } \\
\qquad(\mu \mathrm{m})\end{array}$ \\
\hline E. faecalis & $1.26 \pm 0.08$ & $1.22 \pm 0.08$ & $1.63 \pm 0.14$ & $4.76 \pm 0.54$ & $1.17 \pm 0.15$ & $1.05 \pm 0.14$ & $0.60 \pm 0.13$ & $0.950 \pm 0.022$ & $0.775 \pm 0.077$ & $0.231 \pm 0.025$ \\
\hline E. faecium & $1.25 \pm 0.02$ & $1.05 \pm 0.09$ & $1.60 \pm 0.20$ & $4.21 \pm 0.22$ & $1.28 \pm 0.04$ & $1.11 \pm 0.05$ & $0.66 \pm 0.13$ & $1.000 \pm 0.020$ & $0.809 \pm 0.085$ & $0.157 \pm 0.035$ \\
\hline S. thermophilus & $1.29 \pm 0.14$ & $0.98 \pm 0.15$ & $1.47 \pm 0.18$ & $4.52 \pm 0.67$ & $0.99 \pm 0.26$ & $1.06 \pm 0.45$ & $0.72 \pm 0.07$ & $0.940 \pm 0.024$ & $0.849 \pm 0.041$ & $0.230 \pm 0.010$ \\
\hline L. lactis & $1.17 \pm 0.14$ & $1.17 \pm 0.15$ & $1.37 \pm 0.15$ & $4.26 \pm 0.38$ & $1.34 \pm 0.29$ & $0.84 \pm 0.09$ & $0.72 \pm 0.08$ & $0.960 \pm 0.020$ & $0.851 \pm 0.049$ & $0.253 \pm 0.093$ \\
\hline L. cremoris & $0.97 \pm 0.09$ & $0.81 \pm 0.08$ & $1.13 \pm 0.13$ & $3.10 \pm 0.31$ & $0.69 \pm 0.15$ & $0.49 \pm 0.19$ & $0.73 \pm 0.08$ & $1.000 \pm 1.000$ & $0.869 \pm 0.049$ & $0.243 \pm 0.137$ \\
\hline P. acidilactici & $0.99 \pm 0.06$ & $0.87 \pm 0.03$ & $1.11 \pm 0.11$ & $3.32 \pm 0.43$ & $0.73 \pm 0.09$ & $0.50 \pm 0.08$ & $0.79 \pm 0.07$ & $0.980 \pm 0.027$ & $0.891 \pm 0.044$ & $0.250 \pm 0.053$ \\
\hline Co. Var.\% & 7.63 & 10.63 & 9.74 & 10.59 & 3.63 & 21.73 & 13.2 & 4.58 & 6.52 & 29.84 \\
\hline
\end{tabular}


Bacterial cells roundness: Roundness was measured through the 2 dimension image analysis. The maximum roundness for cells of the tested strains was 0.959 for $P$. acidilactici grown in M17 broth and the minimum was 0.489 for E. faecium grown in milk with an average between $0.639 \pm 0.058$ to $0.805 \pm 0.078$. Roundness values for cocci strains cells grown in both media showed more cells far away from being a perfect circle (0.639) as found for S. thermophilus grown in M17 broth which indicated irregular circles. On the contrary, P. acidilactici and $S$. thermophilus growing in milk (0.805 and 0.735 , respectively), L. lactis subsp. lactis, $(0.796,0.736$, respectively) and L. lactis subsp. cremoris $(0.722,0.767$, respectively) grown in M17 broth and milk had close to circle shapes.

Bacterial cells solidity: Solidity is a measure describing the resemblance of the shape's areas with their convex area. All cocci strains convex area matched their shape's area with the least value of 0.908 . The variation in solidity within strains $(\mathrm{LSD}=0.267)$ was minimal and all values exceeded 0.9 at $\alpha=0.05$. E. faecium and L. lactis subsp. cremoris convex areas perfectly matched their shape's area. Means solidity did not differ from the maximum or minimum values as the range was narrow fall around 1.

Bacterial cells compactness: Compactness is a measure expressing how compact a feature is. Bacterial cells of measured strains were compacted with a value close to 1 . The highest compactness (0.979) was noticed with $P$. acidilactici grown in M17 broth and the maximum mean compactness of $0.897 \pm 0.044$ when grown in milk which indicated more compacted cells than the other strains. The minimum value was 0.699 for E. faecium grown in milk. No significant differences were found between $S$. thermophilus grown in milk, L. lactis subsp. lactis and L. lactis subsp. cremoris grown in both media ( $\mathrm{LSD}=0.046, \alpha=0.05$ ) however bacterial strain significantly affected the cells compactness $(\mathrm{P}<0.05)$, while type of medium that bacteria grown in insignificantly influenced the cells compactness.

Bacterial cells roughness: In order to quantify the surface irregularities of the bacterial cells, surface topography roughness was characterized and quantified for each strain and imaged at different sample positions. Figure 2 showed that the surfaces of the cells were practically non smooth, with irregularities. All the parameters are based on two-dimensional standards that were extended to three dimensions (Figure 3).

The roughness average, $\mathrm{Sa}$, is defined as:

$$
\boldsymbol{S}_{a}=\frac{1}{M N} \sum_{k=0}^{M-1} \sum_{l=0}^{N-1}\left|\boldsymbol{Z}\left(\boldsymbol{x}_{\boldsymbol{k}} \cdot \boldsymbol{y}_{l}\right)\right|
$$

The roughest surface bacterial cell $(19.131 \mathrm{~nm})$ was reported for E. faecium grown in M17 broth, while the smoothest was found with $L$. lactis subsp. lactis $(12.064 \mathrm{~nm})$ as shown in Figure 3 . Significant differences $(\mathrm{P}<0.001)$ were found between bacterial strains in roughness as influenced by strain and medium type.

The Surface Kurtosis, Sku, describes the "peakedness" of the surface topography and is defined as:

$$
S k u=\frac{1}{M N S_{q}^{4}} \sum_{k=0}^{M-1} \sum_{i=0}^{N-1}\left[z\left(x_{k}, y_{l}\right)\right]^{4}
$$

The surface structures of the bacterial cells were somewhat rough and irregular. The external boundary was either a sharp outline or a rough surface, from one cell to another. The surfaces of the cells seemed to have heights or extrudes, in rough cells. Peakedness showed the highest value with $P$. acidilactici cells $(32.367 \mathrm{~nm})$, while the lowest was reported with $L$. lactis subsp. lactis $(13.10 \mathrm{~nm})$ when grown in M17 broth. On the contrary, growing them in milk produced cells with higher peakedness for L. lactis subsp. lactis than P. acidilactici strains as shown in Figure 3, which may attributed to the growing medium ingredients that favor the organism.

Bacterial cells hardness: L. lactis subsp. lactis grown in M17 broth had the maximum hardness $(50484 \mathrm{mN})$ while, it had the lowest $(1284.6 \mathrm{mN})$ when grown in milk which indicated that milk reduced the hardness of this organism (Figure 4). A Grand Mean of $16668.994 \mathrm{mN}$ was obtained for hardness of the spherical particles of bacterial cells. Significant differences were found within strains (LSD value $=0.9203$ at 0.05 a level) in hardness as a result of growing medium type $(\mathrm{P}<0.001)$.

Bacterial cells' wall thickness: Growing in milk reduced the cell wall thickness of E. faecalis, E. faecium, S. thermophilus and $P$. acidilactici on the contrary of L. lactis subsp. lactis and L. lactis subsp. cremoris (Table 1) which were increased. Means of cell wall thickness were ranged between 0.157 and $0.292 \mathrm{~mm}$ for E. faecium grown in milk and $0.292 \mathrm{~mm}$ for E. faecium grown in milk and in M17 broth, respectively

\section{Rheological and technological properties of LAB}

Viscosity, shear stress and torque of milk at $\mathbf{p H ~ 4 . 6 : ~ A t ~} \mathrm{pH} 4.6$, S. thermophilus scored the lowest values for viscosity, shear stress and torque, while, L. lactis ssp. cremoris showed the maximum values. In

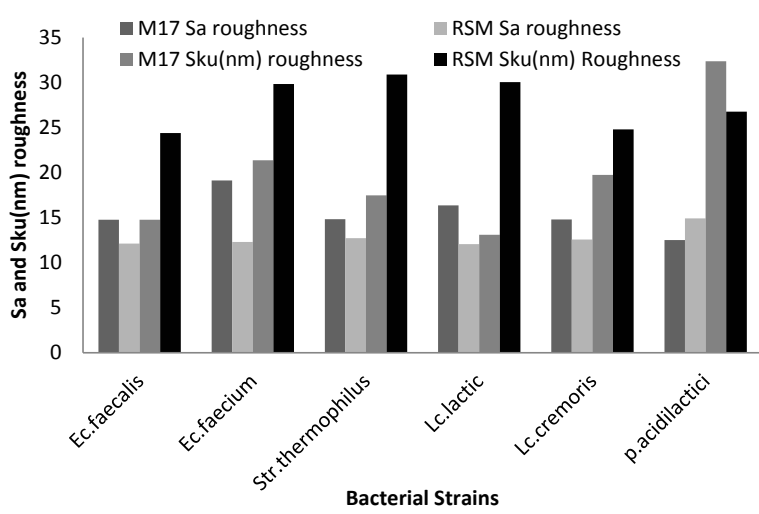

Figure 3: Average cells surface roughness (Sa) and surface kurtosis, (Sku, $\mathrm{nm}$ ) for cocci strains of LAB grown in M17 broth and RSM.

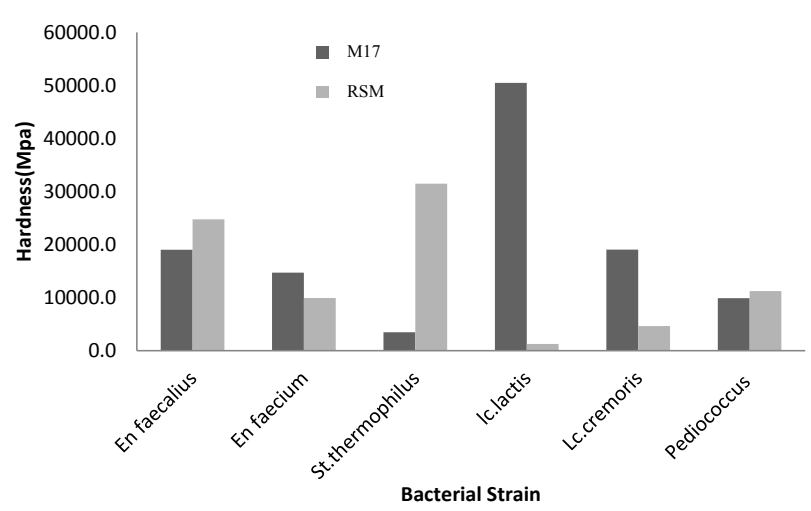

Figure 4: Average cells hardness (MPa) for LAB grown in M17 broth and RSM. 


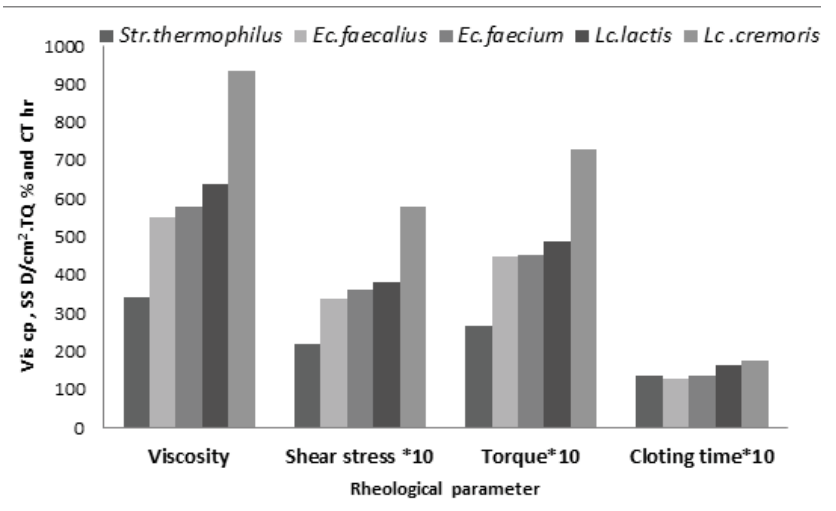

Figure 5: Average viscosity (V), shear stress (SS), torque (T) and clotting time values of milk at $\mathrm{pH} 4.6$ ascending order, S. thermophilus, E. faecalis, E. faecium, L. lactis ssp. lactis and L. lactis ssp. cremoris represented their values (Figure 5). Similar results were previously obtained by [22]. Clotting time at pH 4.6 for L. lactis ssp. cremoris was the longest $(17.7 \mathrm{~h})$ which agreed with the results obtained results results obtained by [23]. While, $S$. thermophilus recorded the shortest $(12.8 \mathrm{~h})$ which indicated a faster metabolism.

Viscosity, shear stress and torque during milk clotting process: As shown in Figure 6, steep increase in viscosity $(342.2 \mathrm{cP})$ of $S$. thermophilus was observed after $8 \mathrm{~h}$ of incubation, while it occurred after $10 \mathrm{~h}$ for E. Faecium $(549.8 \mathrm{cP}$ ) and L. lactis ssp. cremoris $(854.5 \mathrm{cP})$ with longer clotting time for the later, L. lactis ssp. lactis and $E$. faecalis reached viscosities of 637.1 and $580.7 \mathrm{cP}$, respectively. The maximum shear stress was reached at $12,13,13,16$ and $17 \mathrm{~h}$ for $S$. thermophilus, E. faecium, E. faecalis, L. lactis ssp. lactis and L. lactis ssp. cremoris, respectively.
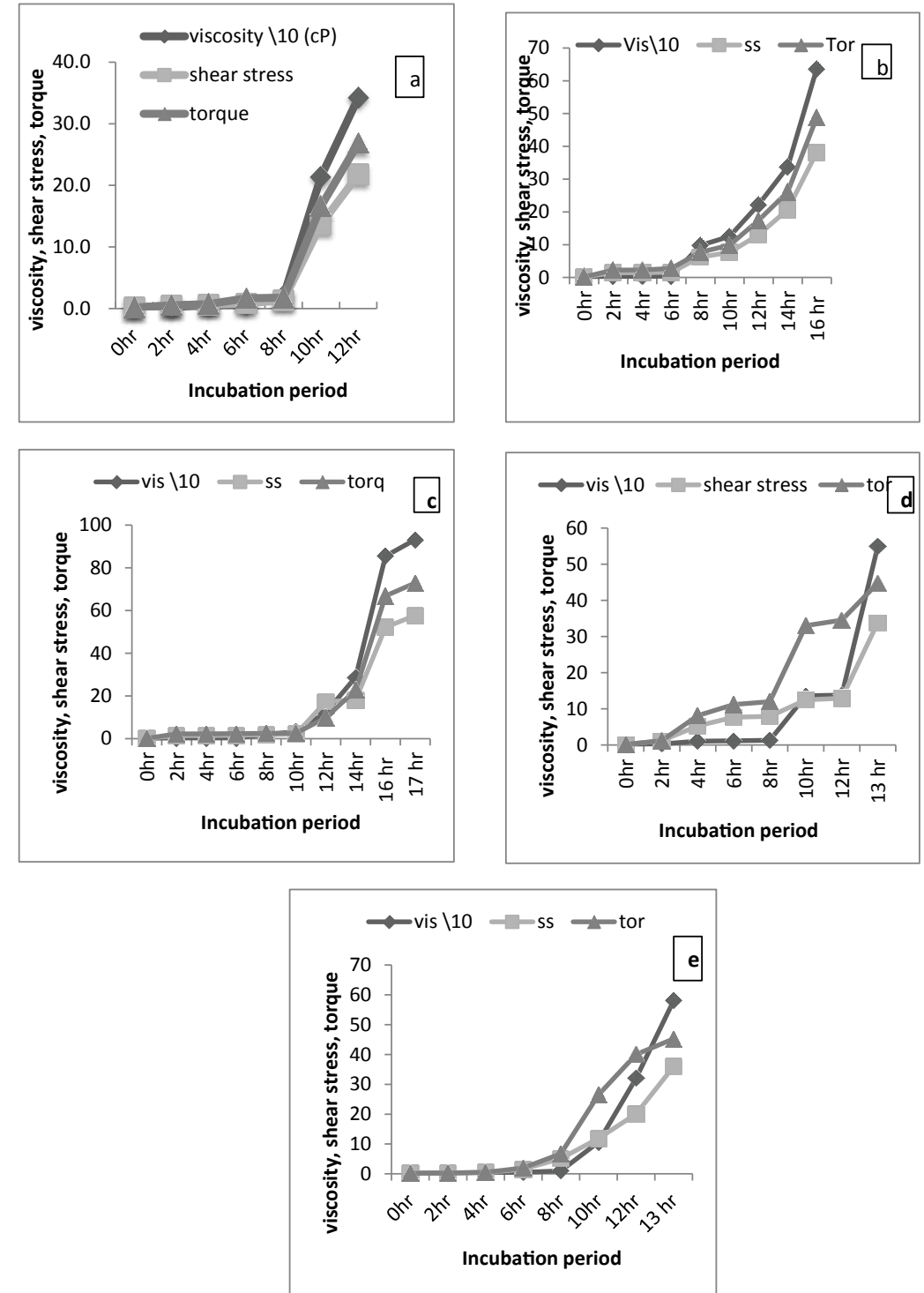

Figure 6: Average viscosity/10 (cP), shear stress ${ }^{*} 10\left(\mathrm{D} / \mathrm{cm}^{2}\right)$ and torque (\%) of RSM through clotting process by S. thermophilus (a), L/lactis ssp. lactis (b), L. lactis ssp. cremoris (c), E. faecium (d) and E. faecalis (e). 
Steep rise in shear stress occurred in the incubation periods of (10-12), (12-13), (12-13), (14-16) and (14-16) h for S. thermophilus, E. faecium, E. faecalis, L. lactis ssp. lactis and L. lactis ssp. cremoris, respectively.

The lowest percent for torque was reached with $S$. thermophilus (26.8\%) and the maximum value was obtained with $L$. lactis ssp. cremoris (66.9\%) which was 2.5 times as $S$. thermophilus value.

Acid production and $\mathrm{pH}$ profiles: The fastest strain reached the iso-electric point ( $\mathrm{pH} 4.6)$ was $S$. thermophilus (12 h), while, L. lactis ssp. cremoris took $16 \mathrm{~h}$ which agreed with that reported by [23]. Average acid production and $\mathrm{pH}$ profile of milk through clotting process by E. faecium $744 \mathrm{~N}$ (a), E. faecalis $780 \mathrm{~N}$ (b) and L. lactis ssp. lactis (c) were shown in Figure 7.

\section{Conclusion}

Great accuracy, repetition and fidelity image analysis technique together with SEM could be a good tool for measuring many

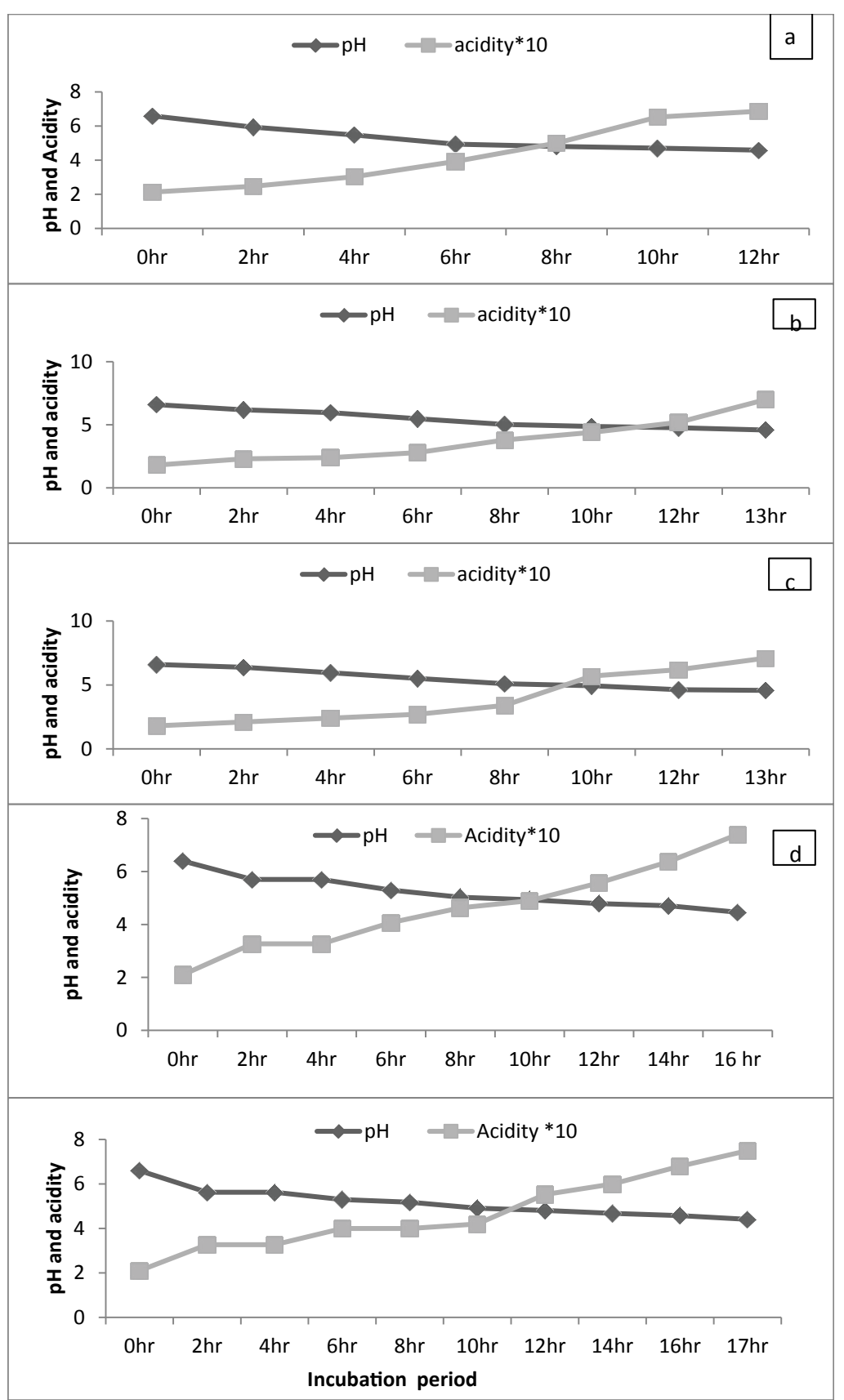

Figure 7: Average acid production and pH profiles of milk through clotting process by S. thermophilus (a), E. faecium (b), E. faecalis (c), L. lactis ssp. lactis (d) and $L$. lactis ssp. cremoris (e). 
Citation: Elzeini HM, Ali AA, Nasr NF, Awad AA, Hassan AA (2017) Morphological and Rheological Identification of Cocci Lactic Acid Bacteria. J Microb Biochem Technol 9: 519-526. doi: 10.4172/1948-5948.1000337

morphological shape and size parameters, for the viable bacterial cells which can be used for characterization of cocci LAB, but growth conditions and growth phase must be determined as effective factors and standard conditions. Additionally, rheological and technological properties could be useful aid for characterizing many bacterial species.

\section{References}

1. Wood B J B, Holzapfel W H (1995) The genera of lactic acid bacteria. Glasgow UK: Blackie academic and professional.

2. Prescott LM, Harley JP, Klein DA (1996) Microbiology. Third Edition, Wm. C. Brown Pub. Dubuque, lowa: 390-414.

3. Carpenter A E, Thouis R Jones, Michael R Lamprecht, Colin Clarke, In Han Kang, et al. (2006) Cell Profiler: Image analysis software for identifying and quantifying cell phenotypes. Genome Biol 7: R100.

4. Mitchison TJ (2005) Small-molecule screening and profiling by using automated microscopy. Chembiochem 6:33-39.

5. Taylor DL, Giuliano KA (2005) Multiplexed high content screening assays creates a systems cell biology approach to drug discovery. Drug Discov Today: Technologies 2: 149-154.

6. Abraham VC, Taylor DL, Haskins JR (2004) High content screening applied to large-scale cell biology. Trends Biotechnol 22:15-22.

7. Bjorklund M, Taipale M, Varjosalo M, Saharinen J, Lahdenpera J, Taipale J (2006) Identification of pathways regulating cell size and cell-cycle progression by RNAi. Nature 439: 1009-1013.

8. Ohya Y, Sese J, Yukawa M, Sano F, Nakatani Y, et al. (2005) High-dimensional and large scale phenotyping of yeast mutants. Proc Natl Acad Sci 102: 19015-19020.

9. Levsky JM, Singer RH (2003) Gene expression and the myth of the average cell. Trends Cell Biol 13: 4-6.

10. Sachs K, Perez O, Pe'er D, Lauffenburger DA, Nolan GP (2005) Causal proteinsignaling networks derived from multiparameter single-cell data. Science 308 : 523-552.
11. Chen X, Murphy RF (2005) Objective clustering of proteins based on subcellular location patterns. J Biomed Biotechnol, pp: 87-95.

12. Terzagh IB, Sandine WE (1975) Applied microbiology 29: 807-813.

13. MacFaddin JF (1985) Media for isolation, cultivation, identification, maintenance of bacteria.

14. Sarantinopoulos P, Andrighetto C, Georgalaki D, Rea CM, Lombardi A, et. al (2001) Biochemical properties of enterococci relevant to their technological performance. Int Dairy J 11: 621-647.

15. AOAC (1990) Official Method of Analysis 15th Ed, Association of Official Analytical Chemists Washington DC, USA.

16. MSTAT (1989) Version 4c, Michigan State University, East Lansing, MI, USA.

17. Gill $\mathrm{Jl}$ (1978) Design and analysis of experiments in the animal and medical science. The lowa State University Press, USA.

18. Victoria K, Claudia V, Nadejda BM (2013) Electron microscopy of pharmaceutical systems. Micron 44: 45-74.

19. Hardie JM, Whiley RA (1997) The genus streptococcus. In B. J. B. Wood and W. H. Holzapfel (eds). The genera of lactic acid bacteria. Blackie Academic \& Professional, London.

20. Kokkinos A, Fasseas C, Eliopoulos E, Kalantzopoulos G (1998) Cell size of various lactic acid bacteria as determined by scanning electron microscope and image analysis. Lait 78: 491-500.

21. Mundt OJ (1986) Lactic acid Streptococci: Bergey's manual of systematic bacteriology, The Williams and Wilkins Company, Baltimore, USA.

22. Faber EJ, Zoon P, Kamerling JP, Vliegenthart JF (1998) The exopolysaccharide produced by Streptococcus thermophilus Rs and Sts have the same repeating unit but differ in viscosity of their milk cultures. Carbohyd Research 310: 269-276.

23. Abee T, Wouters JA (1999) Microbial stress response in minimal processing. Int J Food Microbiol 50: 65-91. 